\title{
HISTORICAL AND PEDAGOGICAL ASPECTS OF TEACHING FOREIGN LANGUAGES OF FUTURE PRE-SCHOOL AND PRIMARY SCHOOL TEACHERS IN UKRAINE
}

\section{Liubov Terletska ${ }^{1}$}

DOI: https://doi.org/10.30525/978-9934-588-38-9-16

Abstract. The purpose of the paper is to analyze pedagogical and historical aspects of teaching foreign languages of future pre-school and primary school teachers in Ukraine in the second half of the XX century and today. The theoretical analysis of literature on investigated issue allowed us to define such components of concept «pedagogical conditions of teaching foreign languages» as general pedagogical conditions and special-educational ones. To our mind general pedagogical conditions are: purposefulness of pedagogical process, scientific character of maintenance of education, systematic character and sequence of educational process, consciousness, an activity of students during pedagogical process, the choice of optimal methods, forms, facilities, complexity of education, taking into account individual features of students, durability and effectiveness of the results of education, respect to personality of student in combination with demand. Such special-educational pedagogical terms as teaching of foreign speech activities (listening comprehensive, speaking, reading, writing), taking into account of native language, the maintaince of communicative exercises, personality-oriented teaching, authentic educational materials (textbooks, videomaterial and audiodiofiles, language labs etc.), motivational providing of foreign activity, individualization of process of teaching foreign languages are also very important. On the basis of analysis of archival data it can be asserted that students of pedagogical schools of Ukraine in the second half of the twentieth century had a low level of foreign language because of such reasons: the lack of curricula for teaching foreign languages for pedagogical schools, the reform of the system of educational institutions, the absence of qualified teachers, lack of textbooks and teaching materials

\footnotetext{
${ }^{1}$ Candidate of Pedagogical Sciences,

Lecturer of Foreign Languages and Methodology Department,

Borys Grinchenko Kyiv University, Ukraine

(C) Liubov Terletska
} 
on the foreign language. Consequently, mastering a foreign language is a complex process that consists not only of the ability to read and understand foreign language, but also of the systematic training of speech activity. In our opinion, it is necessary to highlight the following problems of foreign language teaching in modern educational institutions: the desire of students to speak the language quickly and perfectly; uniformity of exercises, lack of situational speech; lack or low level of motivation and interest in language learning; oversaturation of foreign language grammar; lack of a qualified teacher; application of modern methods of foreign language training etc.

\section{Introduction}

The development of Ukraine as an independent state was a prerequisite for changes in public life, which led to the emergence of a new one in pedagogical education, focusing on preserving the experience gained in Soviet times and at the same time making significant changes in the purpose, content and technology of the pedagogical process. Two major trends have been identified in Ukraine's educational policy: the first is the revival of national consciousness, culture and language, and the second is the focus on European and world community, which requires compulsory knowledge of foreign languages.Educational reforms contributed to the emergence of new teaching methods for the development of creative personality, change of the authoritarian style of teaching to a humanistic approach, taking into account the individual characteristics of young people. Foreign language today is a means of intercultural communication, that's why mastering foreign language activities is aimed not only at the development of communicative competence (linguistic, sociocultural, national, linguistic and regional), but also at education by means of foreign language.

The development of the theory and practice of teaching foreign languages of students of pedagogical specialties reflects the long history of transformations in approaches to the organization of the educational process and the search for effective scientific and methodological concepts of foreign language training. Changes in the methodological approaches and technologies of teaching foreign languages should be considered in the broad context of what is happening in the modern globalized world in general and in particular in the field of national pedagogical education, which is on the verge of cardinal modernization. 
Analysis of studies of the vocational orientation of the foreign language learning process revealed the super-competitiveness between the requirements of the standard of higher pedagogical education regarding the knowledge of future teachers of foreign language communication skills and archaic methods, technologies and forms of organization. The practice of teaching foreign languages for non-linguistic specialties in pedagogical universities indicates that despite the general recognition of the need to develop a communicative focus in foreign language learning, the focus of teachers is on developing students' skills necessary for reading and translation of literature. This orientation of learning does not sufficiently help students to acquire a real practice of vocationally oriented communication. At the same time, insufficient attention is paid to the development of intercultural communication skills, the discussion of existing intercultural and professional differences, which does not allow to speak about the formation of complete foreign language communicative competence.

\section{Reforms of education system of Ukraine}

Ukraine's national education system was formed in the 1990s in the context of changing political, economic and cultural life of society. These changes are envisaged by the main provisions of the legislative and regulatory documents, among which the main ones are: the Constitution of Ukraine (1996), the Law of Ukraine «On Education» (1991), the Law of Ukraine «On General Secondary Education» (1999), the State National Program «Education» («Ukraine of the 21st Century») (1993), State Educational Standard of Foreign Language (1998) and others. They identify the main directions of modernization of the content and methods of education and upbringing of the younger generation, which led to the reformation of foreign language training with the improvement of pedagogy in the second half of the twentieth century. Theoretical categories of teaching foreign languages were formed (purpose, tasks, methods), improving the teaching methodology, reforming the goals of learning foreign language activities (from developing reading and translation skills in 1950-1960 years to the transition to productive mastery of a foreign language in 1970-1980 years and to the formation of foreign language communicative competence in 1990-2000 years); communicative, personality-oriented and differentiated approaches were actively implemented. In the context of changing the purposes of foreign language training in educational institutions, it's 
necessary to study and analyze the pedagogical conditions of teaching foreign languages of future students in pedagogical educational establishments of Ukraine in the second half of the twentieth century and nowadays.

The urgent tasks of modern education in the context of European integration processes are the essential updating of the content of education, the search, creation and application of effective forms and methods of teaching to ensure the high quality of youth education. Priority directions of state language education are its continuity in order to ensure compulsory mastering of Ukrainian language and practical mastery of a foreign language in order to develop a high linguistic culture of citizens, to cultivate tolerance to speakers of European and world languages and cultures, to increase the level of foreign language training in European languages. standards.

\section{Pedagogical conditions of teaching foreign languages}

The term «pedagogical conditions» is nowadays widely used in researches as for professional training of young people in educational institutions of various types. Analizing of pedagogical conditions of teaching foreign languages rerequires defining of certain concepts.

In the academic interpretative dictionary of the Ukrainian language the following meanings of the word «condition(s)» are: 1) «a necessary circumstance that makes possible the realization, creation, formation of something or promotes something»; 2) «circumstances, peculiarities of reality, in which something happens or takes place»; 3) «rules that exist or are established in a particular field of life, activities that ensure the normal operation of something»; 4) «the totality of data, the provisions underlying anything» [8, p. 441].

In the philosophical dictionary, «condition» is defined as «a category that reflects the universal relation of things to those factors by which it arises and exists» [11, p. 703].

According to M.I. Konyukhov «condition is a set of phenomena of the external and internal environment, which probably influence the development of a particular mental phenomenon» [4, p. 206].

According to the academic explanatory dictionary, "pedagogical" is one that "meets the rules and requirements of pedagogy" [9, p. 108].

In scientific researches the concept «pedagogical conditions» is defined differently by scientists, but in our opinion, all analyzed definitions have a common basis. Here are some basic approaches to interpreting this term: 
1) a set of objective possibilities, content, forms, methods, pedagogical techniques and material and spatial environment, which are aimed at solving research problems (A.L. Nazarova) [6];

2) the set of objective possibilities of content, forms, methods and techniques of increasing the efficiency of the educational process and material and spatial environment, which ensure the successful solution of the tasks set and designed in the study (I.Y. Aksarina) [1, p. 19];

3 ) circumstances of the process of education and upbringing, which are the result of purposeful selection, construction and application of content elements, methods, as well as organizational forms of learning in order to achieve didactic goals (A.V. Bagdueva) [2, p. 12];

4) a set of objective possibilities of content, forms, methods, pedagogical techniques (R.K. Seriozhnikova, N.D. Parkhomenko, L.S.Yakovitskaya) [7];

5) the peculiarities of the organization of the educational process in the institution of higher education, which determine the results of education, education and development of the student's personality, objectively ensure the possibility of their achievement (A.L. Durmanenko) [3];

6) interconnected set of internal and external parameters performance characteristics that provides high the effectiveness of the educational process and corresponds to the psychological-pedagogical optimality criteria (V.M. Manko) [5, p. 153].

N.T. Tverezovska and L.L. Phillipova, based on the study of pedagogical literature, give the following definitions of the term «pedagogical conditions» by scientists: 1) characterization of the pedagogical environment; 2) circumstances which are necessary for the course of the pedagogical process; 3) factors, ways, directions of pedagogical process; 4) imaginary results of the pedagogical process; forms, methods, pedagogical techniques [10].

We think that pedagogical conditions of teaching are the circumstances, or factors of the pedagogical process necessary to ensure the effective formation of knowledge and skills in accordance with the program requirements of a particular type of educational institution. We define the pedagogical conditions of teaching foreign language as a complex of organizational and pedagogical factors to ensure the formation of foreign language competence.

Based on the analysis of historical sources, methodological and scientific literature on teaching foreign languages in pedagogical institutions we think that it is advisable to distinguish the following pedagogical conditions of 
teaching foreign languages: general and special-subject (organizational-pedagogical, qualifying, conditions of complexity of foreign language learning activities. General pedagogical conditions are the conditions necessary to ensure the effectiveness of education and training. They are based on the principles of the pedagogical process, such as: purposefulness; scientific content of education and upbringing; systematicity and consistency; students' consciousness, activity, creativity; choice of optimal methods, forms, means of training and education; integrated approach to education and training; taking into account the age and individual characteristics of students; strength, awareness and effectiveness of learning outcomes; respect for the personality of the student in combination with the demanding. All these principles are interconnected and mutually supportive. Special-subject pedagogical conditions are the conditions which are necessary for acquiring knowledge, skills and competences in particular subjects, taking into account the peculiarities of their teaching. educational institutions, participants of educational process and teaching methodology. Let's analyze subject-specific pedagogical conditions on the example of teaching foreign languages, whose main purpose is mastering a foreign language as a means of communication, and the implementation in this process of education and development of the student's personality.

In order to ensure the effectiveness of foreign language training in educational institutions, it is necessary to fulfill the following of such special pedagogical conditions as: interconnected learning of foreign language activities (listening, speaking, reading, writing); taking into account native language knowledge; the dominant role of communication exercises; personality-oriented orientation of foreign language learning; providing the educational process with the appropriate material base, including authentic educational materials (textbooks, video and audio equipment, audio files, language offices, etc.); motivational support of foreign language activity; individualization of the foreign language learning process and others. All of these conditions are specific to the subject matter «foreign language» and determine the principles, methods and requirements for foreign language activity for the students during educational process. As subject-specific pedagogical conditions are decisive for various aspects of teaching foreign language, in our opinion, it is advisable to distinguish organizational-pedagogical, qualification-methodological and conditions of complexity of the direction of foreign language educational activity. 
Organizational and pedagogical conditions include the systematicness of foreign language lessons, the presence of a teacher (teacher), a study room (class) in foreign languages, and educational literature (textbooks, manuals, plans, programs). Taking into account the analysis of historical sources and methodological literature on the foreign languages of the chronological boundaries studied, we concluded that the personnel problems with the foreign language teachers in the pedagogical schools of Ukraine, as well as in other educational establishments, were noticeable until the 1980s. The condition of systematic classes depended on the availability of a teacher, although the amount of foreign language literature for students increased, but was insufficient. The qualifying and methodological conditions include:

1) professional qualification of the teacher. The negative tendencies in the preparation of foreign language teachers in the second half of the twentieth century (until 1991) were: excessive ideologization of the educational process, insufficient funding of educational institutions, imperfection of educational and methodological support. The lack of qualified teachers in both pedagogical schools and schools of Ukraine in the second half of the XX century, had a negative impact on the level of knowledge of foreign language of the students. The practical aim of teaching foreign languages was to read a textbook, to translate the texts with a dictionary. For a long time oral language was not a targeted component of the development of foreign language activities. Among the positive changes were the development and improvement of new curricula, the search for effective ways of teaching future pre-school and primary teachers for a work in educational institutions through the organization of pedagogical practices of different types from the second year of study, the increasing number of higher education institutions in Ukraine. In addition, by the 1980s, group forms for students predominated in institutions of higher pedagogical education. Since 1990, there has been an increase in individual forms of work to provide quality training for foreign language teachers in the context of European education;

2) literature on foreign languages (educational programs for pedagogical schools, textbooks and other educational materials for this type of educational institutions). For a long time, foreign language teacher training programs were not developed, and requirements for students from foreign language teachers were taken from secondary school programs (1-2 years of study). Teaching and learning literature (including textbooks) in a for- 
eign language did not meet the basic purpose of teaching - the formation of foreign language speaking, they were oversaturated with grammatical material and too politicized (until 1990) [12].

In our opinion, the conditions of complexity of foreign language teaching activity include providing foreign language lessons with such obligatory target and content components as: complexity (development of all types of foreign language activity: listening, speaking, writing and reading) to ensure the effectiveness of teaching foreign language; foreign language as a goal and as a means of learning; variety of forms of work, communicative orientation of a lesson; motivational support of students' foreign language learning activities; practical orientation; applying a personality-activity approach to teaching a foreign language.

\section{Features of teaching foreign language (historical aspect)}

Teaching foreign language is a complex and multifaceted process of developing foreign language communication skills (listening, reading, writing and speaking) and the implementation in this process of education and personal development of the student. In our opinion, the provision of conditions for the complexity of foreign language learning activities depended on the goals and methods of teaching foreign languages of a certain historical period. The second half of the twentieth century was characterized by a change in the target component of foreign language training for the younger generation, which was a major factor in expanding the content of foreign language education in Ukrainian educational institutions. Based on the results of the study, it is concluded that in the second half of the twentieth century the content of the practical purpose of foreign language training expanded from reading (translated and untranslated) in the 1950s to the formation of foreign language communicative competence in the 1990s. The target component was varied in accordance with educational reforms and the requirements of the society regarding foreign language proficiency of students of educational establishments. The content of the educational aspect became a reflection of the ideology of public policy, which was enriched by other components only in the late 1980s (formation of a student's personality, increasing interest in the country of the language studied, education of patriotism and internationalism by means of a foreign language). Let's analyze the features of teaching foreign language in the second half of the XX century. 


\section{Peculiarities of teaching foreign languages \\ at the second half of the $X X$ century}

\begin{tabular}{|c|c|}
\hline Years & Features of teaching foreign language \\
\hline $1950 \mathrm{~s}$ & $\begin{array}{l}\text { - excessive textbook theorization; } \\
\text { - reading and translating the text as the main types of work in a foreign } \\
\text { language class (practical goal); } \\
\text { - texts on military topics had a «recommended» character; } \\
\text { - increasing attention to the educational influence of foreign language. }\end{array}$ \\
\hline $1960 \mathrm{~s}$ & $\begin{array}{l}\text { - specification of practical purpose and recognition of its leading in relation } \\
\text { to other purposes of foreign language training; } \\
\text { - definition of requirements for training of speech activities (reading, } \\
\text { writing, speaking, listening); } \\
\text { - reducing the educational goal to ideological and political education; } \\
\text { - expanding the content of the general purpose. }\end{array}$ \\
\hline $1970 \mathrm{~s}$ & $\begin{array}{l}\text { - change of formulation of practical purpose for communication in a foreign } \\
\text { language, teaching of foreign language communication; } \\
\text { - general educational purpose - use of foreign language as a means of } \\
\text { communication; } \\
\text { - educational purpose мета to increase interest in the country of the } \\
\text { language studied; development of the personality of the student (student) by } \\
\text { means of a foreign language. }\end{array}$ \\
\hline $1980 \mathrm{~s}$ & $\begin{array}{l}\text { - reduction of practical purpose to the formation of communicative } \\
\text { competence and practical mastery of a foreign language; } \\
\text { - foreign language writing was considered as a means of mastering oral and } \\
\text { reading skills; } \\
\text { - education of internationalism and patriotism as a component of } \\
\text { educational goal. }\end{array}$ \\
\hline $1990 \mathrm{~s}$ & $\begin{array}{l}\text { - strengthening of the national component; } \\
\text { - development of Ukrainian textbooks on foreign languages based on the } \\
\text { principle of variability; } \\
\text { - Transformation of the general purpose of teaching foreign languages for } \\
\text { educational and developmental purposes; } \\
\text { - practical goal - formation of foreign language communicative competence } \\
\text { (linguistic, speech, socio-cultural and general). }\end{array}$ \\
\hline
\end{tabular}

After Ukraine's declaration of independence, the role of national education and respect for the culture of other peoples and nationalities increased. These changes are reflected in the sociocultural competence of foreign language teaching in Ukrainian educational institutions. During this period, the teaching method developed on the basis of a personality-oriented approach.

The results of a comprehensive study of the development of the aim of teaching foreign language in the second half of the twentieth century prove that the condition of complexity of foreign language activities began to be 
realized only in the 1990s according to the backdrop of transformational processes in the content of Ukrainian education. It should be emphasized that the requirements for the subject «foreign language» in the pedagogical schools of Ukraine of the studied period changed according to the revision of the aim of foreign language education, improvement of teaching methods and language policy of the state.

Therefore, pedagogical conditions are a set of organizational and pedagogical factors for ensuring the effectiveness of the educational process. Pedagogical conditions are an integral part of the pedagogical system (holistic pedagogical process); reflect the totality of the educational environment. Pedagogical conditions for learning foreign languages - a set of organizational and pedagogical factors to ensure the formation of foreign language communicative competence (linguistic, speech, socio-cultural, national, and regional competences).

Theoretical analysis of the interpretations of this concept allowed us to distinguish and characterize pedagogical conditions in the context of foreign language teaching as a set of general and special-subject conditions (organizational-pedagogical, qualification-methodological and conditions of complexity of the direction of foreign language educational activity).

In our opinion, the main aim of teaching foreign languages of pre-school teachers and primary teachers of Ukraine in the second half of the twentieth century was:

1) language competence - mastering new lexical units in accordance with topics and areas of communication within the foreign language programming material;

2) speech competence - developing and improving communicative language skills (reading, listening, speaking, writing);

3) educational and cognitive competence - development of skills of educational and search activity for mastering a foreign language;

4) sociocultural competence - students' acquisition of sociocultural knowledge about the country of the language studied, the ability to compare common and different in the culture of their country and the country whose language was studied;

5) development and education of the younger generation: personal self-determination regarding the future profession, interest in independent language learning and its practical use, social adaptation, formation of qualities of citizen and patriot. 
Foreign language education in pedagogical educational establishments reflects changes in the approaches and priorities of youth language training in the search for the most effective method. The assertion that knowledge of a foreign language is an essential condition for the success and competitiveness of a modern specialist is well known, but we must recognize that the level and quality of foreign language training in Ukraine does not meet the current requirements of the European Community. Establishing economic, educational, political and cultural ties with other countries requires a restructuring of the existing methodology of teaching foreign languages in educational institutions. Ukraine's accession to the Bologna Process created the preconditions for the development of new curricula and textbooks for the formation of a high level of foreign language competence.

Nowadays, mastering a foreign language is obligatory not only for students but also for teachers of educational institutions. The Ministry of Education and Science of Ukraine has developed typical foreign language educational programs for pre-school, general secondary, vocational, higher, extracurricular, inclusive education, methodological recommendations for teachers and lists of recommended educational and methodical literature, electronic textbooks, etc.

Despite the wide variety of textbooks by both Ukrainian and foreign authors, the continuity and systematic preparation of foreign language training in educational institutions, the opportunity to learn a foreign language through the Internet (using online courses, electronic textbooks, authentic literature, communication in subjects. e.) students have difficulty learning a foreign language. First of all, they are related to the lack of motivation to master the language, so the teacher's task is to find effective ways to improve it. Modern teacher should have creative ability to apply problematic methods according to the set goal (project method, brainstorming, discussion, role-playing). These methods contribute to the development of students' communicative competence and increase their interest in learning the language. The use of different methods and techniques of foreign language training can be effective only if the student wants to speak the language. In addition, a significant impediment to mastering a foreign language competence is the different levels of language proficiency and ability to teach students in groups. Consequently, mastering a foreign language is a complex process that consists not only of the ability to read and understand foreign 
language, but also of the systematic speech activity.In our opinion, it is necessary to highlight the following problems of foreign language teaching in modern educational institutions:

1) the desire of students to speak the language quickly and perfectly;

2) uniformity of exercises, lack of situational speech;

3) lack or low level of motivation and interest in language learning;

4) oversaturation of foreign language grammar;

5) the lack of a qualified teacher capable of developing an individual program of foreign language learning with the avoidance of mastering difficulties and a system of exercises for more effective perception;

6) application of outdated methods of foreign language training;

7) constant corrections and remarks regarding pronunciation, errors, etc;

8) unfavorable atmosphere in class and others.

The practice of communication is crucial in language teaching, so the most important task of the teacher is to find effective methods and techniques that will avoid or minimize the occurrence of difficulties.

The achievements of teachers and methodologists of foreign languages of the last century are important for preserving the continuity and possibility of influencing the educational processes of modern Ukraine for the development of a well-developed, gifted, creative personality. The main priority of Ukraine's policy is European integration, which is the force for the development of economic, cultural and educational processes of our country. The goals of the reforms are to create a national education system capable of providing a high level of training for foreign language specialists, preserving the past, and creating a new one in accordance with the state's capabilities and needs. However, there are contradictions between the importance of foreign language acquisition by Ukrainian citizens and the level of foreign language training in secondary and higher education institutions.Foreign language teaching begins in pre-school educational institutions, new methods of foreign language training, new professional and educational literature have emerged, but the level of foreign language proficiency in high school graduates remains low, especially in rural areas.

Let us carry out a comparative analysis of foreign language training of young people in the educational institutions of the second half of the last century and the beginning of the XXI century (modern period). In the 1950s and 1960s, the problem of low level of foreign language knowledge of high 
school students and students of pedagogical colleges of the USSR was recognized by the government of public education, but some steps were taken to improve it, but there weren't expected significant results. Today, the state has created conditions for improving the level of foreign language skills of the young generation, such asnamely: foreign language skills are compulsory for pupils of secondary schools, the study of a second foreign language is introduced from the 5 th grade, the foreign language methodology is built according to the communicative direction - oral communication in a foreign language with an understanding of the interlocutor of the interlocutor). Secondary secondary schools in Ukraine give their students a high level of knowledge in the basics of different sciences, but in our opinion, foreign language training is not enough.

According to the results of the state final certification and external independent assessment of foreign languages, the level of knowledge of graduates does not meet the school assessment of academic achievement, students have gaps in knowledge of this subject, especially grammar, do not understand the value of new lexical units, which leads to difficulties in understanding [13]. The search for effective methods, updating the content of foreign language teaching in secondary pedagogical institutions of Ukraine became especially widespread in the second half of the last century (since the 1970s). Ukrainian methodologists, scientists, teachers studied the advanced experience of foreign colleagues, tried to translate the best practices into the practice of foreign language training of students and students of secondary educational institutions of Ukraine. Among the achievements are the following: continuity of foreign language education; communicative approach to teaching foreign languages as a basis for effective mastering of a foreign language; improvement of normative documents and educational-methodical literature on teaching of foreign languages in secondary and higher educational establishments; ensuring the implementation of cross-curricular links and taking into account the mother tongue; relevance of educational textbooks to the main purpose of foreign language training - oral language teaching; strengthening the requirements for the professional qualification of foreign language teachers for pedagogical colleges and colleges of pedagogical profile. Of course, the experience of native pedagogy and foreign language teaching should be considered in comparison with modern education without bias and stereotypes, rejecting such 
negative phenomena as «ideologization» and «politicization» of teaching. It cannot be argued that the Soviet education system was ineffective, as the government paid attention to the problems of its development. Party leadership understood that education plays an extremely important role in state-building. The work of all educational institutions was based on work training and harmonious upbringing of school-age children and youth, indicating the great importance of pre-school education, vocational education, the spread of political education, etc. Priority pedagogical areas of education in the Soviet period were: the unity of purpose and objectives at all levels; the commitment, gratuity and community of both sexes in vocational and vocational high schools and colleges; the benefit of receiving workers and peasants from children at all institutions; separation of schools from the church, prohibition of religious education and upbringing of children. Great importance in Soviet secondary education institutions was paid to the patriotic upbringing that provided moral and ethical foundations for young people's sense of national dignity and sound moral standards. Students of pedagogical schools were accustomed to diligence, neatness, respectful treatment of adults, fulfillment of daily duties, and their moral development was facilitated by a humane and friendly attitude towards the elderly.

In our opinion, the main goals of teaching foreign languages in the pedagogical schools of Ukraine in the second half of the twentieth century were:

1) language competence - mastering new lexical units in accordance with topics and areas of communication within the foreign language programming material;

2) speech competence - developing and improving communicative language skills (reading, listening, speaking, writing);

3) educational and cognitive competence - development of skills of educational and search activity for mastering a foreign language;

4) sociocultural competence - students' acquisition of sociocultural knowledge about the country of the language studied, the ability to compare common and different in the culture of their country and the country whose language was studied;

5) development and education of the younger generation: personal self-determination regarding the future profession, interest in independent language learning and its practical use, social adaptation, formation of qualities of citizen and patriot [12]. 
According to the allocated goals of teaching foreign languages students of the pedagogical school were required to:

- to know / understand: the meaning of lexical units according to the subject and communication situations, the particular culture of the country of the language studied; the meaning of grammatical phenomena; authentic literature on authentic literature on science and culture, history and modernity, rules of linguistic and non-linguistic communication;

- to have: a) speaking skills (verbal speaking): to engage in dialogue, conversation, to participate in the discussion of a read (heard, seen) foreign language, following the rules of etiquette; to speak about themselves, their preferences within the framework of the program requirements and topics defined by the program requirements; b) reading skills: to read authentic texts of different genres and styles, using basic reading (study, study, search / review), depending on the communicative purpose; c) skills of foreign language writing: to be able to write personal letters, fill in the questionnaire, information about yourself in a foreign language; copy foreign language texts in words; d) skills of foreign language listening: to understand the interlocutor in everyday communication, to understand the main content of audio and video texts (announcements, weather forecast, interviews, reporting) in accordance with topics and program requirements;

- to use the acquired knowledge and skills of foreign language in practical activities and daily life.

The main drawbacks of the Soviet education system are the over-centralization, totalitarian communist ideology, "residual" funding for education, lack of methodological support for teachers at all levels, and the closed nature of the system and, as a consequence, the inability to evolve and adapt to new conditions and needs of society. According to the researchers, the school instilled in children passive consumption - uncritical perception of the existing social order by means of discipline and regulation.

\section{Achievements and disadvantages}

With regard to foreign language training of the younger generation in secondary education in the second half of the twentieth century, it is worth mentioning the following achievements: coverage of issues of improving foreign language learning, advanced pedagogical experience in periodicals; publication of a large number of scientific articles and research in 
communicative linguistics, psychology and pedagogy; development of new methods of teaching foreign languages (personality, activity, communication) and reorientation of learning to the student's personality; improving plans and programs, finding effective foreign language teaching methods and tools.

Issue of scientific and methodological literature for the teacher and various manuals, audio and video materials; strengthening the requirements for the personality of the teacher, improving his professional skill; the focus of public policy on improving the teaching of foreign languages, as evidenced by a number of regulations, orders and instructions; discussing the state of foreign language education of different types of educational institutions during pedagogical readings, meetings, congresses, conferences.

The disadvantages of organizing foreign language training in educational institutions in the second half of the XX century, according to scientists were: determining the influence of socio-political factors on the content, forms and methods of learning foreign languages; excessive ideologization and politicization of the foreign language learning process; imperfection of teaching methods, domination of native language lessons; misstatement of the target component of language learning, focus on the formation of receptive skills, rather than «live communication»; unification of the educational process, impossibility of personally-oriented learning; prevalence of groupgroup teaching methods over personality-oriented ones; lack of proper technical base and appropriate development of information and communication technologies of foreign language training; the formal acquisition of knowledge, which resulted in the ideology of people who could not realize their foreign language knowledge in a closed external society, and therefore deep knowledge was not necessary for life. These negative trends were traced back to 1991, when Ukraine was part of the Soviet Union.

In secondary and secondary specialized pedagogical educational establishments, foreign language training was carried out according to unified (without the right of teachers or institution management) programs and educational and methodical literature for all institutions of the Union Republics. After Ukraine's declaration of independence, the methodology of teaching foreign languages began to develop on the principles of variability, taking into account age peculiarities, development of a harmoniously developed personality. 


\section{Findings}

In our opinion, it is necessary to highlight such major achievements of teachers in the field of foreign language learning in the second half of the last century, which should be used in modern educational institutions to ensure the effectiveness of language training:

1) the importance of knowledge of the grammar of a foreign language to eliminate further difficulties in comprehending foreign language texts and situational speech;

2) the orientation of the educational process on the personality of students, the development of their creativity and independence;

3 ) increasing the number of foreign language lessons in the curricula;

4) providing a communicative approach, developing a situational foreign language, understanding the interlocutor's language as the main goals of learning foreign languages;

5) development and improvement of educational and methodological literature, increasing requirements for the content of foreign language training of students of pedagogical schools and colleges of pedagogical profile;

6) planning and organization of the educational process in a foreign language.

\section{Conclusions}

Today, the provisions on requirements for the content of foreign language education, on teacher training, the use of various means, teaching methods that ensure the development of creative activity, interest, independence of students of pedagogical schools of Ukraine remain relevant.

Thus, reforming Ukraine's foreign language education was and is important in the implementation of our country's educational processes. Positive changes and achievements of teachers-practitioners, scholars, linguists on the methods of teaching foreign languages in the pedagogical schools of Ukraine in the second half of the last century should become the basis for further reform and improvement of this direction of education in order to increase the efficiency of foreign language education of students of modern institutions.

Efficiency and expediency of using modern pedagogical foreign language teaching methods, application of various forms and types of interactive training contributes to the formation of English communicative com- 
petence of future pre-school and primary teachers. We think that prospects for further research are in further theoretical studies and practical developments of modern pedagogical technologies of teacing foreign languages of students of pedagogical specialties.

The level of knowledge of a foreign language of the student should be considered as an important indicator of success of modern specialist, as a result of his education in the university. Students' ability to study a foreign language is characterized by a system of personality features, such as: an ability to master foreign language skills, understanding of the customs and cultures of other countries, an ability to communicate with native speakers without a translator, an ability to continue to use knowledge, languages in practice, communicating with foreign colleagues.

Teaching foreign language is very important for professional achievements of students and influences for their effective communication in professional environment. Therefore, one of the main tasks of the higher education institution should be to assist first-year students both in professional adaptation and in learning a foreign language according to their future profession.

\section{References:}

1. Aksarina I.Y. (2006). Pedagogicheskie usloviya adaptaczii vy pusknikov shkol na e'tape perekhoda ot obshhego $k$ vy`sshemu professional 'nomu obrazovaniyu [Pedagogical conditions for the adaptation of school graduates at the stage of transition from general to higher professional education] (PhD Thesis). Moskva: Kurgansk University.

2. Bagdueva A.V. (2006). Pedagogicheskie usloviya formirovaniya professional noj gotovnosti budushhikh speczialistov s ispol zovaniem informaczionny' $k h$ tekhnologij (na primere speczial nostej kadastrovogo profilya) [Pedagogical conditions for the formation of professional readiness of future specialists using information technology (for example, cadastral specialties)] (PhD Thesis). Ulan-Ude: Buryatsk University.

3. Durmanenko O.L. (2012). Teoretychnyi analiz poniattia «pedahohichni umovy» $\mathrm{v}$ konteksti monitorynhu vykhovnoi roboty u vyshchomu navchchalnomu zakladi [Theoretical analysis of the concept of «pedagogical conditions» in the context of monitoring educational work in higher education]. Molod i rynok, no. 7(90), pp. 135-138.

4. Konyukhov N.I. (1996). Slovar'-spravochnik prakticheskogo psikhologa [Dictionary-reference of a practical psychologist]. Voronezh: Modek, $224 \mathrm{p}$.

5. Manko V.M. (2000). Dydaktychni umovy formuvannia u studentiv profesiino-piznavalnoho interesu do spetsialnykh dystsyplin [Didactic conditions of formation of students of professional and cognitive interest in special disciplines]. Socialization of personality. Kyiv: Lohos, vol. 2, pp. 153-161. 
6. Nazarova O.L. (2003). Novye informatsionnye tekhnologii v upravlenii kachestvom obrazovatel'nogo protsessa $\mathrm{v}$ kolledzhe [New information technologies in the quality management of the educational process in college]. Computer science and education, vol. 11, pp. 79-84.

7. Serozhnikova R.K., Parkhomenko N.D., Yakovytska L.S. (2003). Osnovy psykholohii i pedahohiky: navchalnyi posibnyk [Fundamentals of psychology and pedagogy: a textbook]. Kyiv, $243 \mathrm{p}$.

8. Bilodid I.K. (ed). (1970-1980). Slovnyk ukrainskoi movy: u 11 v. [Dictionary of the Ukrainian language: 11 vol.]. Kyiv: Naukova dumka, vol. 6, 832 p.

9. Bilodid I.K. (ed). (1970-1980). Slovnyk ukrainskoi movy: u 11 v. [Dictionary of the Ukrainian language: 11 vol.]. Kyiv: Naukova dumka, vol. 10, 658 p.

10. Tverezovska N., Fillipova L. (2009). Sutnist ta zmist poniattia «pedahohichni umovy» [The essence and content of the concept "pedagogical conditions»]. Nova pedahohichna dumka, vol. 3, pp. 90-92.

11. Shynkaruk V.I. (ed.) (1986). Filosofskyi slovnyk [Philosophical dictionary]. Kyiv: Holovna redaktsiia URE, $800 \mathrm{p}$.

12. Terletska L. (2019). Features of teaching foreign languages in pedagogical schools of Ukraine in the second half of the XX-th century. Visnyk Kyivskoho natsionalnoho universytetu imeni Tarasa Shevchenka: Pedahohika. Kyiv, 2019. Vol. 9, № 1, pp. 54-58.

13. Terletska L. (2015). Teaching foreign languages at pedagogical schools of Ukraine (the second half of XX century). Science and Education Studies. Stanford University Press, № 2(16) July-December.Volume III, pp. 343-349. 